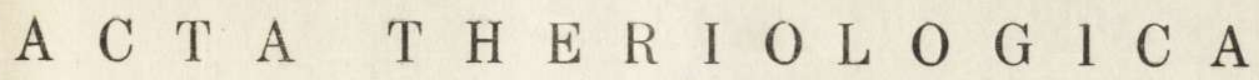 \\ VOL. XII, 2: 17-26. \\ BIAEOWIEŻA \\ 30.III.1967
}

\author{
Svein M YRBERGET
}

\section{The Beaver in Norway}

\author{
Castoriana v.
}

[With 4 Tables \& 4 Figs.]

\begin{abstract}
On the basis of previous literature and a questionnaire survey in $1964-65$, hunting regulations, harvest statistics, distribution and population size over the years, habitat preference, diet, constructions, and destructive activities have been outlined for the beaver Castor fiber L inn a e us, 1758, in Norway. The present population is estimated at about $5,000-10,000$ individuals. Most are found in the southern counties of Vest-Agder, Aust-Agder, and Telemark, but the range is slowly expanding, due in part to invasions from Sweden. Within the main distribution area, there is reason to believe that the population locally may have reached the carrying capacity of its habitat. Beaver have been artificially transported to other parts of the country and released, but apparently in groups too small to be successful, although natural conditions would seem to be suitable for beaver in many regions not presently occupied by them. The beaver is locally considered a pest to forestry and, to some extent, to agriculture. Nevertheless the numbers felled annually are too low at present to influence the population size, and there is reason to expect that in coming years the species will increase both its range and numbers in Norway.
\end{abstract}

\section{INTRODUCTION}

The biology and the distribution of the beaver Castor fiber Lin nae u s, 1758, in Norway up to 1935 have been described mainly by Colle t $\mathrm{t}(1883,1898,1911-12)$ and O ls t a d $(1937,1945)$. Unless otherwise stated, general information in the following stems from these sources.

In order to clarify the present distribution of the beaver in Norway, questionnaires were sent out in the winter of 1964-65 to district game boards, requesting information on local occurrance, numbers of individuals and of occupied lodges, and chief food items. This information supplements that contained in the regular semi-annual game board reports on wildlife population levels, and in regional newspaper articles. The data are still in the process of being analysed, and only a brief summary of the most important findings are presented here. 


\section{HUNTING REGULATIONS}

No special hunting restrictions existed for beaver in Norway until 1845 when the species was declared completely protected. Later from 1855 until 1863, beaver could be hunted throughout the year by landowners on their own property. In 1863 a limited autumn hunting season was initiated, but towards the turn of the century beaver were being locally protected in more and more districts and in 1899 received country-wide protection again, until 1918 when a hunting season was allowed once more. In 1924 total protection was re-established, although since 1925 shooting of beaver has been allowed during a limited fall season in certain townships. The bag limit is determined by the size of the hunting acreage: one beaver for up to 100 hectares, two beaver for $100-200$ hectares, and three beaver on larger territories. Permission can be sought to shoot beaver causing damage, but all forms of trapping are forbidden.

\section{HARVEST}

Statistics are available on the number of beaver bagged between 1927 and 1956 (Table 1), although especially during World War II the data are probably not complete. During these 30 years 1975 beaver have been

Table 1.

Hunting statistics for beaver in Norway 1927-1956.

\begin{tabular}{|c|c|c|c|}
\hline Year & \multicolumn{3}{|c|}{$\begin{array}{c}\text { Number } \\
\text { bagged each year } \\
\text { Minimum }\end{array}$} \\
\hline $1927-31$ & Maximum & 152 & Mean \\
\hline $1932-39$ & 316 & 54 & 227 \\
$1940-44$ & 126 & 2 & 82 \\
$1945-56$ & 47 & 2 & 17 \\
\hline
\end{tabular}

officially bagged, but the annual number decreases markedly. Poaching probably occurs to only a limited extent at present, although occasional instances are known, as are violations involving the use of traps and dynamiting of lodges.

\section{DISTRIBUTION}

Place names, archeological finds, and written records from the 17th century indicate that in early times beaver were common throughout most of the country (Collett, 1898, p. 3-8, 91, 95-101; and also Scha a nning, 1927; W oll eba ek, 1945; J ohnse n, 1946; B a r th, 1957, p. 137; Simc.nsen, 1961; and M örkved, 1961, p. 97).

In the middle of the 18th century beaver were found in a number of localities, with the exception of the west of South Norway. From then 
until about 1850 , numbers declined rapidly until there were stable populations only in the counties of Vest-Agder, Aust-Agder, and Telemark, in the southernmost part of Norway (for location of counties see the map, Fig. 4). With the introduction of complete protection in 1845, the situation reversed and beaver again began populating more and more localities in the south. Fig. 1 gives a summary of the developments from 1896 to 1935 in southernmost Norway. Figs. 2 and 3 show the distribution around 1935 and 1965 respectively. From the maps it is clear that in recent years also beaver have extended their range in Norway. From the main distribution area in the southern part of the country they have spread out into eastern coastal districts, as on the other hand, the species has entirely disappeared from certain other, densely inhabited coastal areas. Beavers have also colonized new regions of the country, especially along the Swedish border where individual animals have wandered in.

Fig. 1. Distribution of the beaver in 1896 (dots), 1910 (dashes), and 1935 (lines). (Redrawn after O Istad, 1937, p. 251),

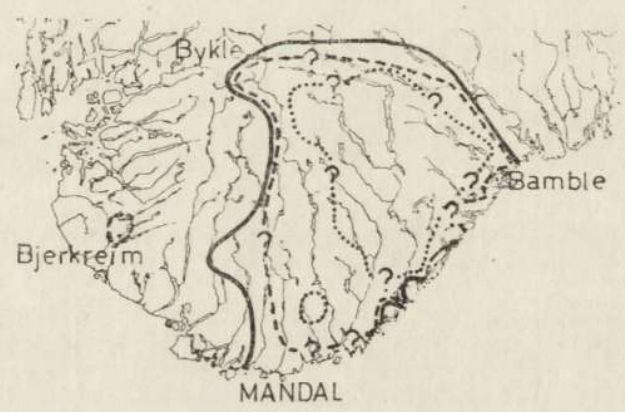

This happened around 1950 in Trysil (H a lvorsen, 1952) where we now have a large population, and in 1957 in Hattfjelldal where there are now one or two families.

In recent years, beaver have been artificially introduced in various places in Norway: in 1925-32, 17 beaver were released on five occasions (Fig. 2), and in 1952-65, 23 beaver were released at four localities (Fig. 3 ). There are probably no survivors at present from those set out prior to 1962 ; since then, too short a time has elapsed to judge whether the efforts will be successful. The poor results of the releasing experiments are possibly due to the fact that too few animals were set out on each occasion. Some of the beaver have been shot illegally, and dispersals of up to $80-100 \mathrm{~km}$. from the point of release have thinned out the local populations in several cases.

\section{NUMBERS}

In 1880 the total Norwegian beaver population was estimated by Cooks (1880) to comprise 60 adults, a figure claimed by $\mathrm{Collett}$ 


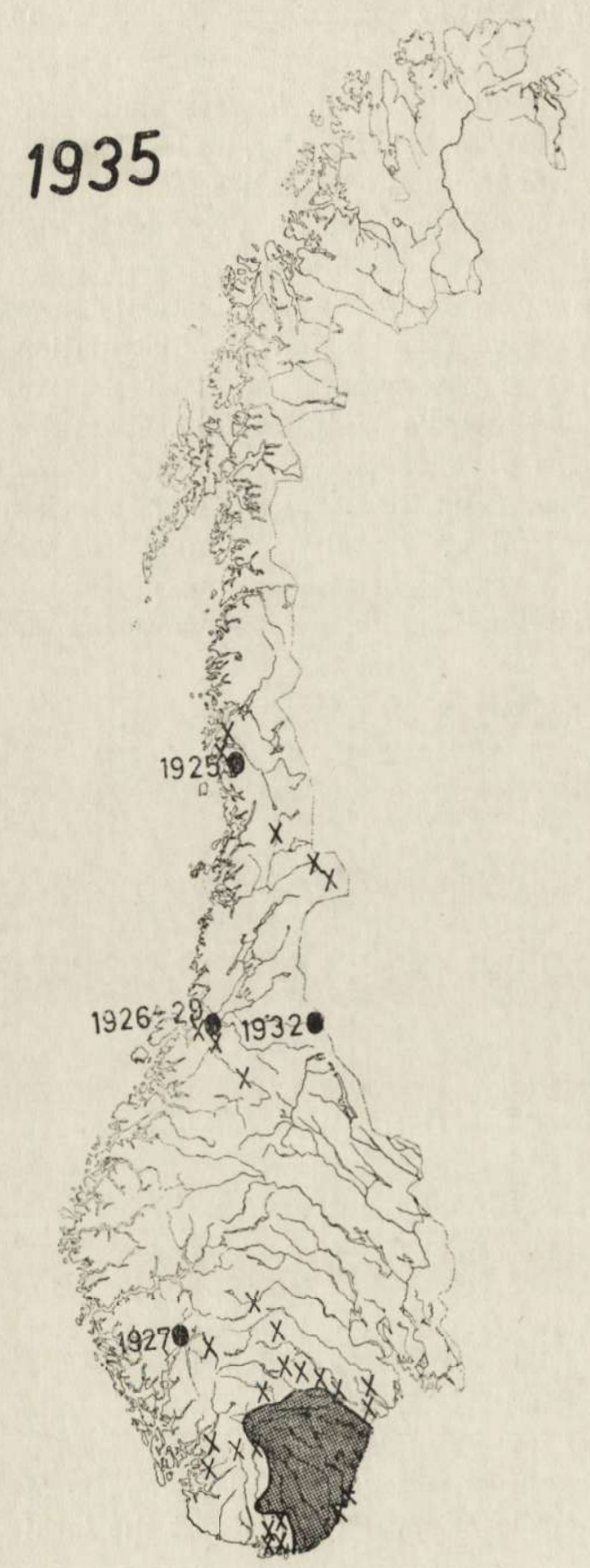

Fig. 2.

1965

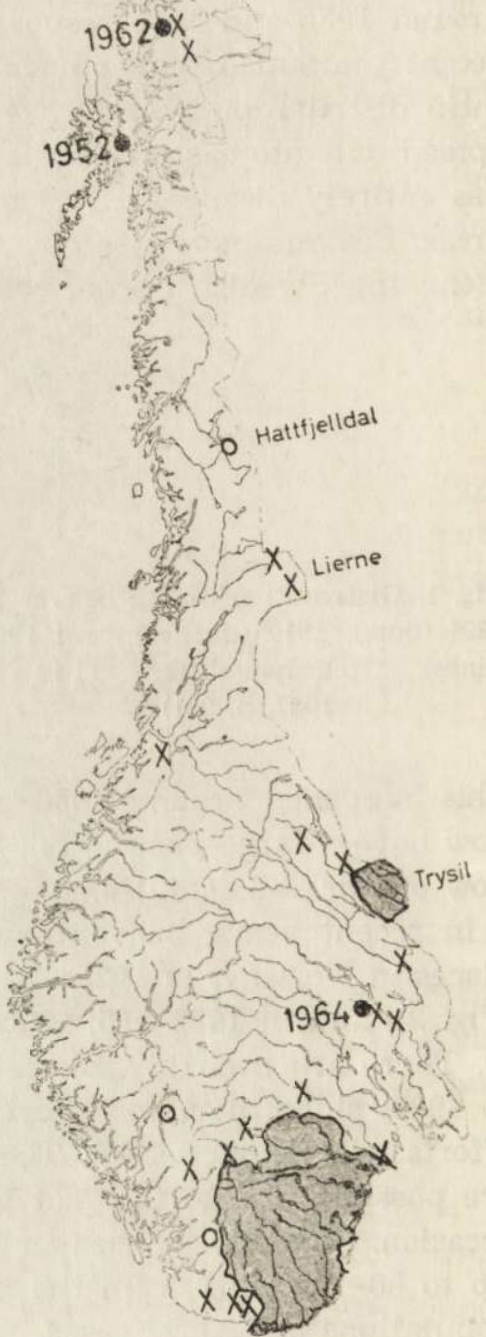

Fig. 3.

Distribution of the beaver around 1935 (Fig. 2) (redrawn after Ols t a d, 1937, p. 247) and around 1965 (Fig. 3). In Fig. 3 stray individuals in 1960-65 are included. Dotted area: main distributional area. Open circles: small established local populations. Filled circles: artifical releases (year of release added). Crosses: townships where stray individuals have been observed. 
(1883) to be about $50 \%$ too low. In 1935 O ls tad (1937) estimated "several thousand animals". At this time, moreover, the population was beginning to decrease in many areas after a peak around 1930. This was blamed largely on hunting, both legal and illegal (Ols t a d, 1937), but according to Simonsen (1965a) the drop-off could also locally have been due to the fact that beaver were overeating their food supply.

During the war years $1940-45$ there were at least local declines in beaver many places due to poaching, but in recent years there has been a steady increase in numbers (Table 2).

The present population has been calculated on the basis of local game board reports to be about 5,000 of which about 4,500 are evenly distributed among the counties of Telemark, Aust-Agder and Vest-Agder.

It is difficult to determine the reliability of such reports from local observers. In some cases the reported number of lodges is probably too high, as some non-active lodges may have been included; in other cases not all of the active lodges are discovered, and the number is probably

Table 2.

Number of reports mentioning increasing stable, or decreasing population.

\begin{tabular}{|l|l|rrr|rrr|rrr|r|r|}
\hline \multirow{2}{*}{ Year } & \multirow{2}{*}{ Reporter } & \multicolumn{3}{c|}{ Telemark } & \multicolumn{3}{c|}{ Aust-Agder } & \multicolumn{3}{c|}{ Vest-Agder } \\
& & & Inc. Stable & Dec. & Inc. Stable & Dec. & Inc. Stable & Dec. \\
\hline 1935 & O l s t a d, 1937 & 5 & 1 & 5 & 2 & 5 & 16 & 10 & 1 & 3 \\
1948 & Game report & 3 & 13 & 2 & 3 & 15 & 4 & 3 & 15 & 6 \\
1958 & Game report & 6 & 13 & 1 & 15 & 11 & 1 & 8 & 10 & 2 \\
$1962-63$ & Game report & 19 & 23 & 2 & 20 & 13 & 1 & 15 & 14 & 2 \\
$1964 / 65$ & Questionnaire & 10 & 3 & 0 & 12 & 5 & 0 & 13 & 4 & 0 \\
\hline
\end{tabular}

too low. The only special beaver census undertaken recently in Norway is from a part of Kristiansand Township in Vest-Agder County, where in the winter of $1964-65$ a density of 30 occupied lodges per $100 \mathrm{~km}^{2}$ was found (S i mons en, 1965a). The game board report for this whole township, including also non-typical beaver habitat, was "at least" 25 lodges per $100 \mathrm{~km}^{2}$.

By dividing the number of beaver reported by the game boards by the number of lodges reported, we get about 2.2 beaver per lodge in practically all of the townships. Sim on sen (l.c.) estimates 3-6 beaver per lodge, in Sweden the average is 4.9 , and in Maine, USA 4.3 ( $\mathrm{L} \mathrm{u} \mathrm{n} \mathrm{d} \mathrm{b} \mathrm{e} \mathrm{r} \mathrm{g}$ et al., 1965; Hogdon \& $\mathrm{Hunt}, 1953)$. This is about twice the game board number, and suggests that the Norwegian population may possibly be, in fact, between 5,000 and 10,000 beaver. In the following, however, all officially reported figures will be cited as reported.

Game boards report a population averaging 14 beaver per $100 \mathrm{~km}^{2}$ within the main distribution centre, and somewhat higher in the westernmost (Vest-Agder) than in the easternmost (Telemark) county (Table 3 ). 
O ls t a d (1937) has given the number of occupied lodges reported by local observers for certain townships, and although these would hardly be representative for their respective counties as a whole, a comparison with recent data (Table 4) may give a reasonable idea of population density in 1935 relative to that of 1964 . In the (easternmost) districts of Telemark there has been, in places, a sharp increase, in Vest-Agder

Table 3.

Beaver density in the counties of Telemark, Aust-Agder, and Vest-Agder in relation to total area and area of suitable habitat defined as the sum of forest, cultivated land, and bodies of water. For the location of Coastal Areas, Forest and Farmland. and Highlands (Mountain valleys and fells), see Fig. 4.

\begin{tabular}{|l|c|c|}
\hline \multicolumn{1}{|c|}{ Area } & $\begin{array}{c}\text { No. beaver per } \\
100 \mathrm{~km}^{2} \text { total area }\end{array}$ & $\begin{array}{c}\text { No. beaver per } \\
100 \mathrm{~km}^{2} \text { suitable habitat }\end{array}$ \\
\hline Telemark & 9.6 & 30 \\
Aust-Agder & 18 & 42 \\
Vest-Agder & 18 & 58 \\
All three counties & 54 & 100 \\
Coast & 22 & 42 \\
Forest and Farmland & 2.2 & 11 \\
Highlands & 14 & 40 \\
Total & & \\
\hline
\end{tabular}

Table 4.

Comparison of numbers in 1935 and 1964 in areas with established beaver populations both years.

\begin{tabular}{|l|c|c|c|}
\hline \multicolumn{1}{|c|}{ County } & $\begin{array}{c}\text { No. townships } \\
\text { reporting both years }\end{array}$ & $\begin{array}{c}\text { No of lodges } \\
\text { in 1935 }\end{array}$ & $\begin{array}{c}\text { No. of lodges 1964 as } \\
\text { percentage of that in 1935 }\end{array}$ \\
\hline Telemark & 3 & 67 & 390 \\
Aust-Agder & 8 & 312 & 71 \\
Vest-Agder & 7 & 128 & 223 \\
\hline Total & 18 & 507 & 152 \\
\hline
\end{tabular}

a slower increase, and in part of Aust-Agder a reduction in number of occupied lodges. For the three counties as a whole, the data suggest an increase of $50 \%$ within thase townships which had established beaver populations both years in question.

\section{HABITAT PREFERENCE}

The beaver is found in lakes and along waterways from the coast all the way up to mountain areas where it lives in the Salix zone. In valleys it is usually found on the valley floor or on plateaus above, seldomly on the steeper side slopes (Y. Hagen, pers. comm.). Beaver are also found near brackish water, and, occasionally, swimming in the sea. In the Kristiansand area the majority of lodges are in lakes and ponds, and only a few in rivers and streams (S i m o n s e n, 1965a).

As seen from Table 3 and Fig. 4, beaver occur in greater densities in coastal areas than in forest and agricultural districts, and only in small 
numbers in mountains. (This difference may, however, not represent the actual situation as relatively more lodges may have been overlooked in the forest and mountain areas.) There are relatively few beaver in the forest districts in Telemark, which consist mainly of conifers, and in the heavily populated coastal regions of Aust-Agder.

\section{CONSTRUCTIONS}

Beaver dams and lodges in Norway are described by Collett and $\mathrm{Olstad}$, and by Simonsen (1965b). Greatest length recorded in the literature for a dam is $21 \mathrm{~m}$, but dams of larger dimensions are said to

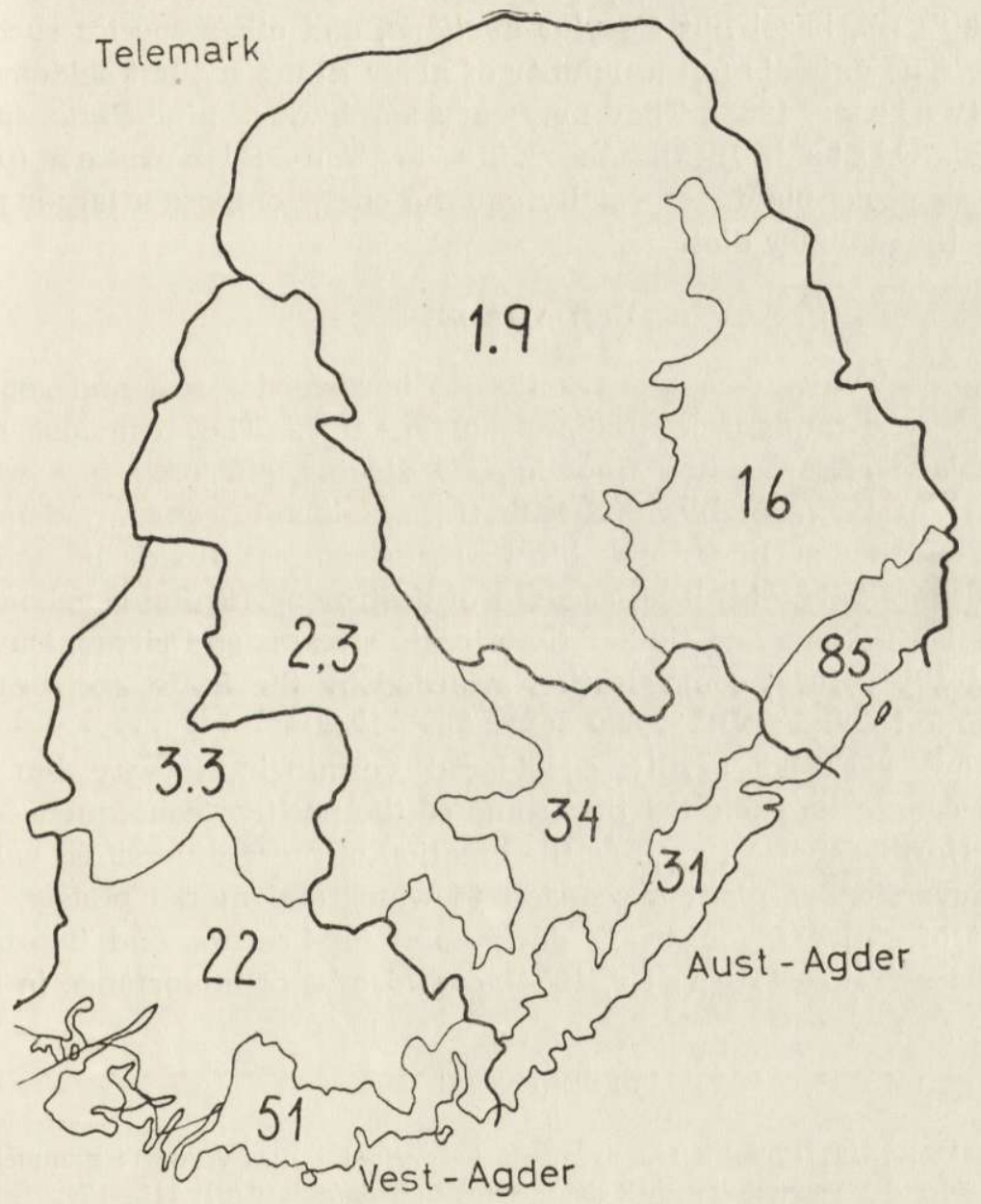

Fig. 4. No. of beaver per $100 \mathrm{~km}^{2}$ total area in the counties of Telemark, AustAgder, and Vest-Agder. Heavy lines: County borders. Light lines: borders between the natural habitats such as Coastal areas (to the south and south-east). Forest and Farmland, and Highlands. 
occur. Two types of lodges can be distinguished: oblong and round; the former are found mostly in localities such as rivers where the water level varies greatly.

\section{FOOD}

The diet of the beaver in Norway is said to consist mainly of fresh bark, small twigs and sap of various deciduous trees. The poplar Populus tremulus is preferred (Olstad, 1957), but since birch Betula sp. is so abundant in Norway, this is also an important food plant here. Beaver is also fond of oak Quercus sp., rowan Sorbus aucuparia, willows and sallows Salix sp., hazel nut Corylus avellana, and other species such as fruit trees. The animals fell a number of alder Alnus sp., but seldom eat the bark (V a l e u r, 1965). They may eat some bark of pine Pinus sp. in the spring (Olstad, 1945). According to Tore Simonsen (pers. comm.) herbaceous plants, especially aquatic ones, compose a larger proportion of the summer diet.

\section{DAMAGE}

Beaver occasionally cause destruction to hardwood forest and conifer plantations by damming streams and cutting trees. They can also ruin cultivated land and roads by flooding and digging, and once in a while are known to take vegetables and fruit trees. Seldomly can they damage telephone and power lines and block roads and railroads by felling timber. Beavers have also been accused of destroying fishing gear and of hindering fish passage and timber-flotation in streams and rivers. During the period 1914-1925, compensation awarded by the State for beaver damage came to about NK 32,500 (O l s t a d, 1945).

Beaver are at least locally considered vermin in Norway, but the possibility cannot be excluded that some of the positive consequences of beaver in North America, such as the creation of more diversified valley habitats, reversion of plant succession to water and marsh phases, improvement of streams for trout, ducks, and fur-bearers, and improvement of moose range (Y e a g e r, 1954), can also be of importance in this country.

\section{REFERENCES}

1. Barth E. K., 1957: Trekk fra dyrelivet i Torridal i Vest-Agder i gammel og ny tid. Torridal Sorenskriveri. Kristiansand S (Högfeldt A/S): 111-174.

2. Collett R., 1883: Om baeveren (Castor fiber) og dens udbredelse i Norge fordum og nu. Nyt Mag. Nat. vid., 28, 3. Raekke 2: $11-45$

3. Collett R., 1889: Baeveren i Norge, dens udbredelse og levemaade. Bergens Mus. Aarbog 1897: 1-127. 
4. Collett R., 1911-12: Norges Pattedyr. Kristiania (Aschehoug \& Co.), 735 pp.

5. Cooks H., 1880: The beaver in Norway. The Zoologist, 3, 4: 233-36 \& 497501.

6. Halvorsen H. E., 1952: Bever (Castor fiber) i Trysil og Engerdal. Fauna 5: $146-47$.

7. Hogdon K. W. \& Hunt J. H., 1953: Beaver management in Maine. Maine Dep. Inland Fish \& Game, Game div. Bull., 3: 1-102.

8. Johns on S., 1946: Jordfunn av bever fra Stavanger til Trondheimsfjorden. Naturen, 70: 156-59.

9. Lundberg S., Petters on J. O. \& W ein berg U., 1965: Bävern. Sveriges Natur 56: $134-142$.

10. Mörkved K. L., 1961: Beveren i Nord-Tröndelag. Fauna 14: 94-106.

11. Olstad O., 1937: Beverens (Castor fiber) utbredelse i Norge. Nytt Mag. Nat. vid., $77: 217-73$.

12. Olsta d O., 1945: Jaktzoologi: Landpattedyrene. Oslo (Cappelen), 249 pp.

15. Olstad O., 1957: Beveren. Norges Dyreliv I (ed. B. Föyn \& J. Huus, Oslo, Cappelen, 535 pp.): 147-164.

14. S ch a anning H. T. L., 1927: Kjendte fugl-arter fra Norges sten- og jernalder. Stavanger Mus. Arsh., 35 (1924-25): 1-25.

15. Sim on s en P., 1961: Varanger-funnene II. Tromsö Mus. Skr., 7, 2: 1-525.

16. Simonsen T., 1965a: Telling av beverhytter i Kristiansand vinteren 1964/65. Kristiansand Mus. Ārbok 1965: 15-29.

17. Simons,en T., 1965b: Om beverens byggevirksomhet. Teknisk Ukebiad: $473-77$.

18. Valeur P., 1965: Bever (Castor fiber L.). Kristiansand Mus. Årbok 1965: $5-14$.

19. W oll e baek A., 1945: Bever i Östfold i tidligere dager. Naturen, 69: 381 .

20. Yeager L. E. \& H i11, R. H., 1954: Beaver management problems on western public lands. Trans. 19th N. A. Wildlife Conf.: $462-80$.

Received 17 August, 1966.

The Norwegian State Game Research Institute,

Vollebekk, Norway.

Svein MYRBERGET

БОБР В НОРВЕГИИ

Рез юм е

На основании литературных данных и опроса, проведенного в 1964-1965 гг., определяется необходимое регламентирование охоты, статистика продуктивности, распространение и размеры популяции на протяжении ряда лет, стациальное распределение, а также питание, полезная и вредная деятельность бобра Castor fiber L in n a e s, 1758, в Норвегии. Современное поголовье вида выражается цифрой от 5000 до 10000 экз. Наибольшая численность наблюдается в южных областях Вест-Агдер, Ост-Агдер и Телемарк, однако ареал вида имеет тенденцию к расширению, в частности, за счет пришельцев из Швеции. Есть основания полагать, 
что в пределах основной области обитания бобры приурочены лишь к местам, наиболее для них подходящим. Бобров искусственно переселяли в другие районы страны и там выпускали, однако переселяемые группы были слишком малочисленны для того, чтобы подобное мероприятие могло увенчаться успехом, несмотря даже на то, что места, подходящие для жизни бобров имеются во многих районах, где в настоящее время бобр не встречается. В некоторых местах бобр может вредить лесному и, в некоторой мере, сельскому хозяйству. Однако количество истребленных зверей слишком мало, чтобы оказать заметное влияние на общее поголовье, так что имеются все основания ожидать, что в ближайшие годы ареал вида в Норвегии будет расширяться, а его численность увеличиваться.

Svein MYRBERGET

\section{BOBR W NORWEGII}

\section{Streszczenie}

W oparciu o dane z literatury oraz wyniki ankiety przeprowadzonej w latach 1964-1965, określono przepisy łowieckie, statystyki pozyskania oraz rozmieszczenie i wielkość populacji w ciągu wielu lat, wymogi środowiskowe, pożywienie, budowle oraz szkodliwą działalność bobra, Castor fiber Linnaeus, 1758 w Norwegii.

Obecny stan bobra ocenia się na 5-10 tysięcy osobników. Większość z nich zamieszkuje okręgi poludniowe: Vest-Agder, Aust-Agder i Telemark, ale zasięg bobra powoli zwiększa się, po części dzięki nachodzeniu ze Szwecji. Są podstawy do przypuszczania, że na głównym obszarze zasięgu bobrów w Norwegii, populacja osiągnę-la już lokalnie stan wydolności środowiska (carrying capacity).

Bobry były odławiane, przewożone do innych części kraju i wypuszczane, jednak w zbyt małych grupach by osiągnąć powodzenie. Wydaje się jednak, że w wielu terenach dotychczas przez bobry nieopanowanych są dogodne warunki przyrodnicze dla tego rodzaju akcji.

Bóbr lokalnie uważany jest za szkodnika lasów i w pewnej mierze upraw rolnych. Mimo to ilość bobrów ubitych rocznie jest zbyt niska by wpływało to na wielkość populacji. Należy więc oczekiwać, że zasięg tego gatunku i jego liczebność w Norwegii będzie wzrastać w najbliższych latach. 